\title{
Biodegradation of Linear Alkylbenzene Sulfonate (LAS) by Immobilized Pseudomonas sp.
}

\author{
Aju K. Asok ${ }^{1}$, Pallickalvaliyaveettil Aboobaker Fathima ${ }^{2}$, Manakulam Shaike Jisha ${ }^{{ }^{*}}$ \\ ${ }^{1}$ School of Biosciences, Mahatma Gandhi University, Kottayam, India \\ ${ }^{2}$ M.E.S. College Ponnani, Nedumkandam, Idukki, India \\ Email: ${ }^{*}$ jishams@mgu.ac.in
}

Received 23 June 2015; accepted 8 October 2015; published 12 October 2015

Copyright (C) 2015 by authors and Scientific Research Publishing Inc.

This work is licensed under the Creative Commons Attribution International License (CC BY).

http://creativecommons.org/licenses/by/4.0/

(c) (i) Open Access

\section{Abstract}

Anionic surfactants are the most widely exploited chemical surfactants, which are being incorporated into majority of detergents and cleaning products used for household and industrial applications. Linear alkylbenzene sulfonates (LAS) is one of the major xenobiotic anionic surfactants. Biodegradation is an effective process to reduce the amount of surfactants released in the environment. In this study soil samples were collected from detergent contaminated sites to isolate linear alkylbenzene sulphonate degrading bacteria using mineral salt media supplemented with LAS as sole source of carbon. From the twenty isolates selected for the study, two of them (L9 and L12) have exhibited excellent ability to degrade LAS. The LAS degradation ability was determined by using MBAS assay and HPLC. The selected isolates were immobilized in alginate and polyvinyl alcohol to check the suitability of the isolates in onsite LAS removal. The percentage of degradation of LAS by alginate entrapped L9 was 85.155 \pm 1.2 and that of PVA immobilized cells was 58.535 \pm 2.9. Whereas L12 PVA entrapped were good compared to alginate. L12 exhibited 62.977 \pm 1.3 percentage of degradation of LAS when immobilized in PVA and $61.07 \pm 0.6$ percentage in alginate entrapped condition. In comparison between the organisms alginate entrapped Pseudomonas nitroreducens (L9) was found to be superior to Pseudomonas aeruginosa (L12) in immobilised condition. It was found that immobilized cells performed superiorly than free cells. In particular, calcium alginate immobilised cells were more efficient in LAS removal than polyvinyl alcohol immobilised cells.

\section{Keywords}

Anionic Surfactant, Calcium Alginate, Pseudomonas nitroreducens, Polyvinyl Alcohol

\footnotetext{
${ }^{*}$ Corresponding author.
}

How to cite this paper: Asok, A.K., Fathima, P.A. and Jisha, M.S. (2015) Biodegradation of Linear Alkylbenzene Sulfonate (LAS) by Immobilized Pseudomonas sp. Advances in Chemical Engineering and Science, 5, 465-475. 


\section{Introduction}

Surfactants (Surface-active agents) represent a highly essential and beneficial group of compounds for civilised human communities. Two major types of surfactants are bio-surfactants and synthetic surfactants. Among these, synthetic surfactants are the widespread ones today because they can be produced in bulk to meet the ever increasing demand of the society and have comparatively low production cost. Linear alkylbenzene sulphonate (LAS) is an extensively used anionic surfactant. LAS are frequently used as the sodium salts as the sole surfactant in a formulation or in conjunction with other anionic, nonionic or cationic surfactants. In 2011, Linear alkylbenzene sulphonates (LAS) holds $97.9 \%$ of the market. About $82 \%-87 \%$ of LAS produced is used for the production of household detergents and cleaning products. LAS is also used for the manufacture of heavy-duty laundry liquids, laundry powders, light-duty dish-washing liquids and industrial cleaners. Other applications of LAS include agricultural herbicides, ink solvent, emulsifying agent, anti hygroscopic additives, neutrino detectors, paint industry and electric cable oil.

Along with all its qualities surfactants do have some demerits. These surface active compounds are intensely toxic to living world because it will disrupt membranes and cause proteins to denature [1]. Hence, it's wide spread use and discharge into terrestrial and aquatic environment become a major concern today.

Metabolic activity of microorganisms play pivotal role in degradation and removal of environmental pollutants [2]. Sewage treatment facilities can effectively reduce surfactant concentration. But when present in excess, surfactants produce excessive foaming in sewage treatment plants which can cause operational difficulties. It may also lead to health hazards in the form of air borne pathogens carried on windblown foams. Presence of LAS at a concentration $500 \mathrm{mg} / \mathrm{L}$ is reported to inhibit microbial growth and resist biodegradation [3]. Most of the LAS biodegradation studies were conducted under aerobic condition or in anaerobic condition preceded by a period of aerobic exposure. Under anaerobic conditions LAS is reported to be non biodegradable due to its long exposure time and toxicity [4].

Under natural conditions microorganisms can degrade LAS in a very low rate [5]. One of the greatest constrain of in situ bioremediation applications is the establishment of the desired organism in the toxic environment. The introduced strain has to overcome competition with autochthonous biota in order to establish there.

The use of immobilised microorganisms for the production of various useful chemicals and biodegradation of xenobiotics is an important aspect of microbial technology [6] [7]. Alginate immobilized cells are easily prepared and are more stable than free cells over a long period. The microcarrier was found to be preferable for its simple method of preparation and better operational performance [8].

Physical entrapment of cells inside polymer matrix is one of the most widely used and straightforward techniques for cellular immobilization, since it does not depend significantly on cellular properties. Immobilization of microbial cultures has proved to be advantageous in municipal and industrial sewage treatment because of high degradation efficiency and good operational stability.

Hydro gel materials can be classified into two categories: Natural and synthetic. Alginate is an example for natural matrix and poly vinyl alcohol (PVA) is an example for synthetic matrix. Entrapment in insoluble calcium alginate is recognised as a rapid, non-toxic, inexpensive, versatile method. PVA is widely used for waste water treatment processes. PVA gels are easily prepared from aqueous PVA solutions and have the characteristics of high porosity and stability [7].

Biotechnological approaches such as immobilisation techniques may be used to biodegrade waste to convert the toxicant into nutrient, biomass and $\mathrm{CO}_{2}$ [9]. Hence this study was aimed to test the feasibility of bacterial entrapment technique for the biodegradation of anionic surfactants. Two LAS degrading strains of Pseudomonas, viz. Pseudomonas aeruginosa and Pseudomonas nitroreducens, were immobilized in a natural polymer and a synthetic polymer, poly vinyl alcohol (PVA), and the extent of LAS degradation by the immobilised cells was compared with of free cells in batch culture condition.

\section{Materials and Methods}

\subsection{The Substrate}

Sodium dodecylbenzene Sulphonate $\left(\mathrm{C}_{18} \mathrm{H}_{29} \mathrm{NaO}_{3} \mathrm{~S}\right)$ having formula weight 348.48 and with approximate purity of $80 \%$ supplied by Sigma-Aldrich were used for carrying out the study. 


\subsection{Media Composition and Culture Conditions}

The mineral salt medium used to enrich LAS degrading organisms was composed of ( $\mathrm{g} \cdot \mathrm{l}^{-1}$ of distilled water) $\mathrm{Na}_{2} \mathrm{HPO}_{4}$ (1.6), $\mathrm{K}_{2} \mathrm{HPO}_{4}(1), \mathrm{NH}_{4} \mathrm{Cl}(0.5), \mathrm{K}_{2} \mathrm{SO}_{4}$ (0.06), $\mathrm{CaCl}_{2}$ (0.025), $\mathrm{MgCl}_{2}$ (0.1), Trace element solution 2 ml. Trace element solution consist of $\left(\mathrm{g} \cdot \mathrm{l}^{-1}\right.$ of distilled water) $\mathrm{FeSO}_{4} \cdot 7 \mathrm{H}_{2} \mathrm{O}(0.1), \mathrm{MnCl}_{2} \cdot 4 \mathrm{H}_{2} \mathrm{O}(0.1)$, $\mathrm{ZnSO}_{4} \cdot 7 \mathrm{H}_{2} \mathrm{O}(0.1)$ distilled water $100 \mathrm{ml}$. For the solid media $1.5 \%$ agar was added to the mineral salt medium.

The biodegradation tests with free and immobilized cells were carried out in shaking flasks on a rotary shaker maintained at $90 \mathrm{rev} \cdot \mathrm{min}^{-1} .100 \mathrm{ml}$ mineral salt medium containing $100 \mathrm{ppm}-10,000 \mathrm{ppm}$ LAS as the sole carbon source was used for the study. In free cell experiment $1 \mathrm{ml}$ 1OD (OD at 600) culture was used as the inoculums and for immobilized cell tests 100 beads were taken as the inoculums.

\subsection{Isolation and Identification of Microorganisms}

Soil was collected from different parts of detergent contaminated domestic laundry premises of Meenachil River shore, located in Kottayam, Kerala, India. Suitable dilutions of soil samples enriched in mineral salt media with sole carbon source LAS were isolated on mineral salt agar to isolate the organism of interest. Isolates were purified and stock cultures were maintained in nutrient agar slants.

The efficiency of LAS degradation was assessed by methylene blue active substrate (MBAS) assay [10]. The morphological and biochemical characteristics of the potential isolate were analyzed according to Bergey's Manual of Systematic Bacteriology, and it was further confirmed by the Institute of Microbial Technology, Chandigarh, India. Cultures were deposited in the Microbila Type Culture collection Centre (MTCC), of the Institute of Microbial Technology, Chandigarh, India.

Chromosomal DNA was isolated from $5 \mathrm{ml}$ of Luria bertani (LB Broth) broth culture of the isolate incubated at $37^{\circ} \mathrm{C}$ for $16 \mathrm{~h}$ by alkali lysis method [11]. 16S rDNA typing of the isolate was done using universal eubacterial primers FP: -5'-CAGGCCTAACACATGCAAGTC-3' and RP: -5'-GGGCGGAGTGTACAAGGC-3'. PCR reaction was carried out in Eppendrof AG22331 Thermal Cycler. The PCR product of $1.5 \mathrm{~kb}$ was purified PCR clean up kit-100 (Chromus biotech, Bengaluru) and was sequenced. The sequencing of the amplified region was done using the automated DNA sequencing service provided by Chromus Biotech, India. The sequences were analysed using nucleotide tool BLAST, BLASTN 2.2.24+ version (www.ncbi.nlm.nih.gov/BLAST) [12]. The sequence was deposited in the NCBI gene bank data base.

The phylogenetic analysis of the isolates was done by multiple sequence alignment. The multiple sequence alignment program ClustalW2 (http://www.ebi.ac.uk/clustalw2/). The aligned sequences were organized to reflect sequence homology and the evolutionary distance calculation. A phylogenetic tree was also constructed using neighbour joining method.

\subsection{Immobilization Techniques}

For immobilisation, seed culture was carried out in nutrient broth incubated for 16 - $18 \mathrm{~h}$ on a rotary shaker maintained at $37^{\circ} \mathrm{C}$. The culture broth was centrifuged at $10,000 \times \mathrm{g}$ for $10 \mathrm{~min}$ in REMI cooling centrifuge, and saline washed pellet were used for immobilization

\subsubsection{Alginate Immobilization}

Alginate (4\%) were thoroughly mixed with hot distilled water and then autoclaved. The mixture was cooled to about $30^{\circ} \mathrm{C}-40^{\circ} \mathrm{C}$ and added to a solution of about $1.5 \mathrm{~g}$ wet cell weight per $100 \mathrm{ml}$ of alginate solution. The resulting solution was then dropped in to a solution containing $\mathrm{CaCl}_{2}(0.05 \mathrm{M})$, and slowly stirred for $1 \mathrm{~h}$ to form beads. The spherical beads formed were then kept under agitation for about $2 \mathrm{~h}$ to harden. The beads were finally washed with sterile water and used for immobilized cell experiments.

The modified culture medium for the immobilized cells contained $\left(\mathrm{g} \cdot \mathrm{l}^{-1}\right.$ of distilled water) $\mathrm{K}_{2} \mathrm{HPO}_{4}(0.2)$, $\mathrm{KH}_{2} \mathrm{PO}_{4}(0.1), \mathrm{CaCl}_{2}(0.01)$ [13].

\subsubsection{Calcium Alginate Modified Poly Vinyl Alcohol Immobilization}

$10 \%$ PVA and $0.5 \%$ alginate were thoroughly mixed and heated the mixture until dissolved and then autoclaved. The mixture was cooled to about $30^{\circ} \mathrm{C}-40^{\circ} \mathrm{C}$ and added to a solution of $1.5 \mathrm{~g}$ wet cell weight per $100 \mathrm{ml}$ solution. The resulting mixture was dropped in to a saturated boric acid solution containing $0.3 \mathrm{M} \mathrm{CaCl}_{2} \cdot 2 \mathrm{H}_{2} \mathrm{O}$ and 
gently stirred for $1 \mathrm{~h}$ to form beads. The formed beads were then transferred to a sodium phosphate solution for about $2 \mathrm{~h}$ to harden. The beads were finally washed with sterilised distilled water.

The culture medium for growing immobilized cells was composed of $\left(\mathrm{g} \cdot \mathrm{l}^{-1}\right.$ of distilled water) the following $\mathrm{MgSO}_{4} \cdot 7 \mathrm{H}_{2} \mathrm{O}(0.5), \mathrm{FeSO}_{4} \cdot 7 \mathrm{H}_{2} \mathrm{O}(0.01), \mathrm{K}_{2} \mathrm{HPO}_{4}(0.1), \mathrm{KH}_{2} \mathrm{PO}_{4}$ (0.2), $\mathrm{CaCl}_{2}(0.01)$ and $\mathrm{KCl}(0.1)$ [14].

From the immobilised beads 25 were macerated in sterile glass tube. Then $10 \mathrm{ml}$ trisodium citrate was added and shaken gently for $15 \mathrm{~min}$ for further dissolution of alginate, followed by dilution and plating on nutrient agar for enumeration. Protein content of the biomass was estimated by Folin's phenol method with bovine serum albumin as a standard. The activity of sample was expressed as microgram per bead.

\subsection{Use of Adsorbents for Removing High Concentrations of LAS}

To test the suitability of a naturally available adsorbant for LAS removal, $1 \mathrm{~g}$ of substances such as charcoal, clay, coir pith, rice bran, straw, saw dust and wheat bran were added to $100 \mathrm{~mL}$ LAS containing solution in Erlenmeyer flasks and shaken for $1 \mathrm{~h}$. $1 \mathrm{~mL}$ sample was withdrawn from the flask and MBAS assay was done to check the amount of surfactant removed by the adsorbant.

\subsection{Measurement of LAS Degradation}

The concentrations of anionic surfactant LAS was determined by a modified version of the methylene blue active substance assay (MBAS) as described by [10] Hayashi. The MBAS assay is a non specific analytical method to determine anionic surfactant concentration in a solution using a cationic dye methylene blue. The anionic surfactant will from a complex with the methylene blue and this complex (not excess dye) can be extracted in to chloroform. The absorbance of the chloroform layer at $655 \mathrm{~nm}$ will be directly proportional to the anionic surfactant in the medium. Briefly, aliquots of methylene blue solution $(0.1 \mathrm{ml}), 0.4 \mathrm{ml}$ of $0.825 \mathrm{mM}$ phosphate buffer (pH7.2), and an appropriate volume of sample (up to $1 \mathrm{ml}$, in triplicate) were mixed in acid-washed, optically matched glass tubes $(12 \times 1 \mathrm{~cm}$ internal diameter) and vortexed intermittently five times for $3 \mathrm{~s}$ each time. Chloroform was added to each tube and the contents were vigorously vortexed for $5 \mathrm{~s}$, allowed to stand at $4^{\circ} \mathrm{C}$ for $5 \mathrm{~min}$ and followed by centrifugation at $2000 \mathrm{rpm}$ for $4 \mathrm{~min}$. The tubes were allowed to warm to room temperature, and the absorbance of the chloroform layer was measured at $655 \mathrm{~nm}$ using a UV spectrophotometer, against an appropriate blank.

LAS was measured by reverse-phase high performance liquid chromatography (HPLC), using a C18 column and SPD-20A UV-VIS detector $(220 \mathrm{~nm})$. The mobile phase was an aquous solution of acetonitrile with $1 \mathrm{M}$ sodium perchlorate. The flow rate was set to $1 \mathrm{ml}$ per minute. Data acquisition and processing were performed by using LC solution system (Shimadzu) [15].

\subsection{Phytotoxicity Assay}

Seed germination of rice (Oryza sativa) was used to assay the phytotoxicity ofas per Ecological Effects Test Guidelines OPPTS 850.4200 Seed Germination/Root Elongation Toxicity Test. Surface sterilized seeds were separated into appropriate size classes. Fresh test solutions were added to Petri dishes that have been completely filled with an inert material. The seed were then positioned on the substrate allowing adequate room for anticipated growth. Petri dish lids were used to hold the seed in place, and the dishes sealed with tape. The dishes were placed in a seed germinator or other growth facilitator at a slightly tilted angle to facilitate linear root growth. Seeds were incubated in the dark until at least $65 \%$ of the control seed have germinated and developed roots that are at least $20 \mathrm{~mm}$ long.

The number of seed that germinated was counted, and root lengths measured. The number of germinated seeds on each treatment was recorded up to seven days and final percentage of germination was calculated. The germination rate was calculated by dividing the number of normal seedling obtained at each counting in the standard germination test by the number of days seeds had been in germinator. The values obtained at each count are then summed at the end of the germination test to obtain the germination rate [16].

$$
\text { Rate }=\left(\frac{\text { Number of normal seedling }}{\text { Days to first count }}+\cdots+\frac{\text { Number of normal seedlings }}{\text { Days to final count }}\right)
$$

Vigor index of seedling was calculated according to [17] as germination percentage multiplied by seedling 
total length i.e. total shoot and root length. Concentration response curves, $\mathrm{EC}_{10}$, and $\mathrm{EC}_{50}$ for seed germination and root elongation was determined.

\section{Results}

Twenty bacterial isolates were obtained from detergent contaminated soil samples. From among the isolates two namely L9 and L12 were selected for further studies. Both the organisms were Gram negative bacilli. In nutrient agar plates, L9 formed round, convex, opaque colonies where as L12 formed irregular, convex, and opaque colonies. In nutrient broth L9 produced a cream colour pigment and L12 a red colour pigment. In King's B agar after incubating for $48 \mathrm{~h} \mathrm{~L} 12$ was found to produce green fluorescent pigment. Both the isolates were motile and non spore former. The isolates were found to grow in the temperature range $10^{\circ} \mathrm{C}-42^{\circ} \mathrm{C}$ and can tolerate a pH ranging from $\mathrm{pH} 5.0$ to $\mathrm{pH}$ 8.0. Both the isolates were able to ferment lactose and utilize citrate. L9 is nitrate reducer and L12 was found to produce $\mathrm{H}_{2} \mathrm{~S}$ and liquefies gelatin. Based on the results L9 was identified as Pseudonomas nitroreducens and L12 as Pseudomonas aeruginosa (Figure 1). The identification was confirmed by MTCC, and the cultures were deposited under the MTCC accession number MTCC10463 and MTCC 10462 respectively.

The percentage of LAS degradation by the free cells were found to be $81.35 \pm 1.5$ (L9) and $80.41 \pm 1.8$ (L12) at $100 \mathrm{ppm}$ LAS concentration (Table 1). But when the concentration of LAS increased from 100 to 10,000 ppm the degradation efficiency was found to be reduced. Immobilised cells showed better degradation efficiency compared to free cells. L9 in alginate entrapped cells degrade maximum LAS compared to PVA entrapped cells. The percentage of degradation of LAS by alginate entrapped L9 was $85.155 \pm 1.2$ and that by PVA immobilised cells were $58.535 \pm 2$.9. It was found that PVA entrapped L12 was efficient compared to alginate. L12 exhibited $62.977 \% \pm 1.3 \%$ degradation of LAS when immobilised in PVA and $61.07 \pm 0.6$ in alginate entrapped condition.

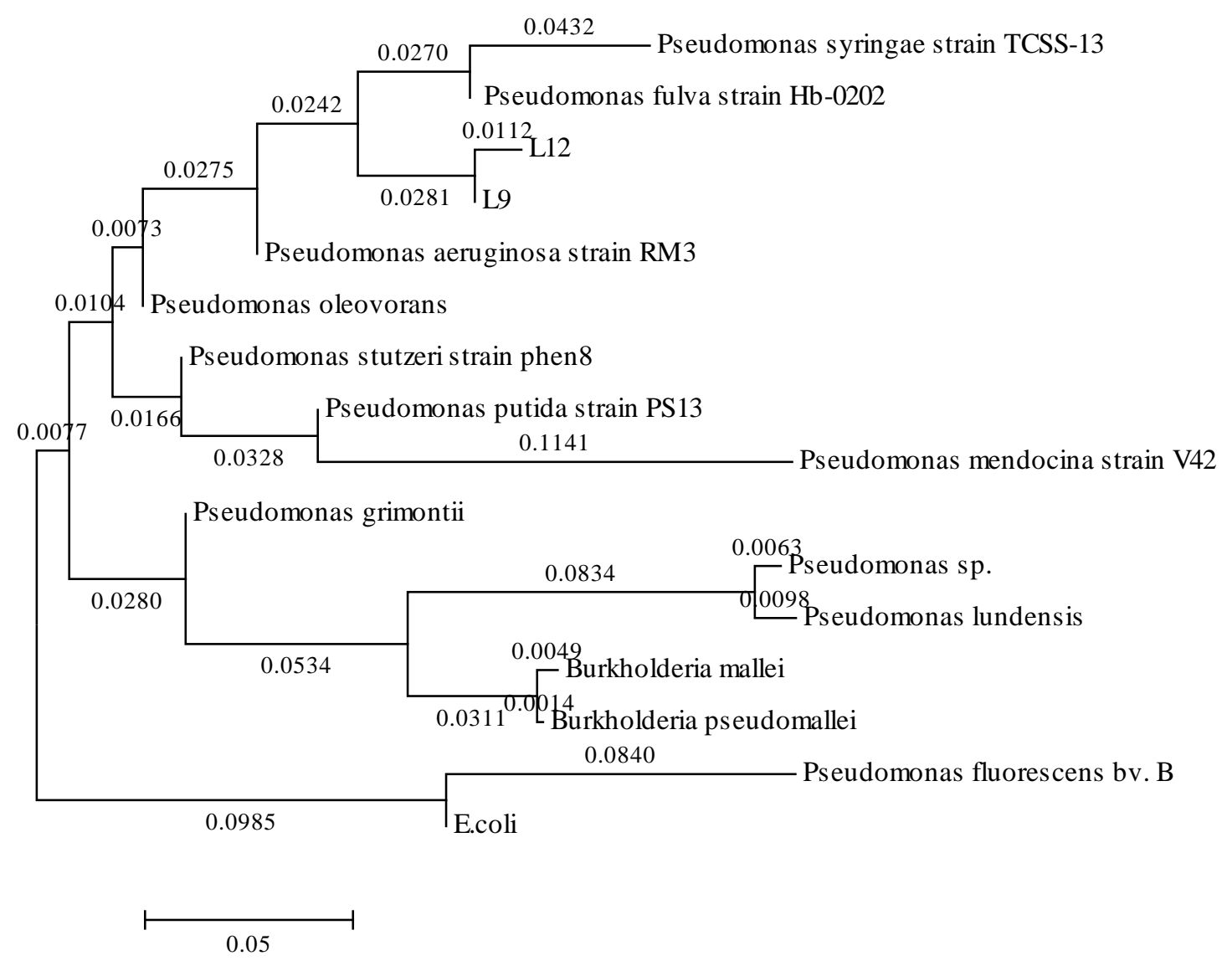

Figure 1. Phylogenetic tree of the isolates generated using neighbor joining method. 
Table 1. Table showing results of percentage of degradation by the isolates in free cell and immobilized cell experiment (LAS percentage 1\%, Days of incubation 3 days).

\begin{tabular}{cccc}
\hline & \multicolumn{2}{c}{ Percentage of degradation } \\
\cline { 2 - 4 } Isolate & Free cells & \multicolumn{2}{c}{ Immobilized cells } \\
\cline { 2 - 4 } & & Alginate entrapped & PVA entrapped \\
\hline Pseudomonas nitroreducens (L9) & $57.35 \pm 1.5$ & $85.16 \pm 1.2$ & $58.54 \pm 2.9$ \\
Pseudomonas aeruginosa (L12) & $57.41 \pm 1.8$ & $61.07 \pm 0.6$ & $62.98 \pm 1.3$ \\
\hline
\end{tabular}

The MBAS assay results were supported by the HPLC chromatogram of the immobilized cells. The HPLC analysis of the selected isolates (Table 2) showed a marked reduction in concentration of the LAS compared to control. Pseudomonas nitroreducens (L9) showed maximum reduction in peak area as compared to Pseudomonas aeruginosa (L12). L9 in alginate entrapped state showed an average of 94.137\% reduction in peak area and 64.296\% in PVA matrix. L12 reduced peak area to an extent of $84.081 \%$ in PVA entrapped application and $81.524 \%$ in alginate entrapped application compared to control. This also supports the finding that L9 entrapped in alginate is very efficient in LAS removal.

Results of LAS removal efficiency by the selected adsorbants are given in Table 3. It was found that coir pith could remove about 52\% LAS from solution.

A range finding test was done for paddy seeds to find the approximate test solution concentration (Table 4 \& Plate 1). Twenty paddy seeds were exposed to four different LAS concentration. A control treatment was maintained without LAS. It was found that LAS concentration between $1 \mathrm{mg} / \mathrm{L}$ and $10 \mathrm{mg} / \mathrm{L}$ is adversely affecting the germination percentage. In this range it was observed that the germination rate reduced more than $50 \%$. At the highest LAS exposure concentration $(1000 \mathrm{mg} / \mathrm{L})$ there was no germination.

In order to determine concentration response curve 15 paddy seeds were exposed to six different concentrations of LAS (Table 5). The percentage of inhibition was calculated. It was found that when seeds were exposed to $4 \mathrm{mg} / \mathrm{L}$ LAS the percentage of inhibition was 7.14 and it became 64.28 when concentration increased to 64 $\mathrm{mg} / \mathrm{L}$. Based on these findings the $\mathrm{LC}_{50}$ was calculated using probit analysis (Table 6). The $\mathrm{LC}_{50}$ value was found to be $9.526 \mathrm{mg} / \mathrm{L}$ LAS having a lower limit of $6.775 \mathrm{mg} / \mathrm{L}$ and an upper limit of $13.251 \mathrm{mg} / \mathrm{L}$ with 95\% confidence limits.

\section{Discussion}

Synthetic surfactants have become indispensable both in household and personal hygiene products and in very diverse industrial applications. Anionic surfactants are currently the types most used, and among them linear chain alkylbenzenesulfonate are the most popularly used synthetic anionic surfactants [18]. Increased use of anionic surfactants in detergent formulations leads to the dumping off these chemicals into water bodies. Hence the concentration of these products in surface waters has increased drastically, leading to different pollution problems. Although they are readily degraded by bacteria in sewage treatment plants and receiving lakes and streams [19] the bulk of discharged chemical and anaerobic condition leads to increase the residual concentration of the chemical in the environment. LAS has bactericidal activities and at high concentration it may destroy the microbiota of the waste water treatment facility including LAS degrading bacteria. In such scenario immobilized surfactant degrading bacteria could be effectively and economically exploited for onsite removal of excess surfactant concentration [20].

The results of this study suggested that LAS degradation by immobilised cells was superior than that of free suspended cells. If the degradation efficiency of the isolate Pseudomonas nitroreducens (L9) was examined, it was found that the isolate is performing well in immobilised condition.

Initially the LAS degradation was studied in free cells. As evident from the results (Table 1) the percentage of degradation of the free cells were found to be $57.35 \%$ (L9) and 57.41\% (L12). When immobilized there was an increase in percentage of degradation. L9 in alginate entrapped cells degrade maximum LAS compared to PVA entrapped cells. The percentage of degradation of LAS by alginate entrapped L9 was $85.155( \pm 1.2) \%$ and that of PVA immobilized cells was $58.535( \pm 2.9) \%$. Whereas PVA entrapped L12 were good compared to alginate. L12 exhibited $62.977 \pm 1.3$ percentage of degradation of LAS when immobilized in PVA and $61.07 \pm 0.6$ in 


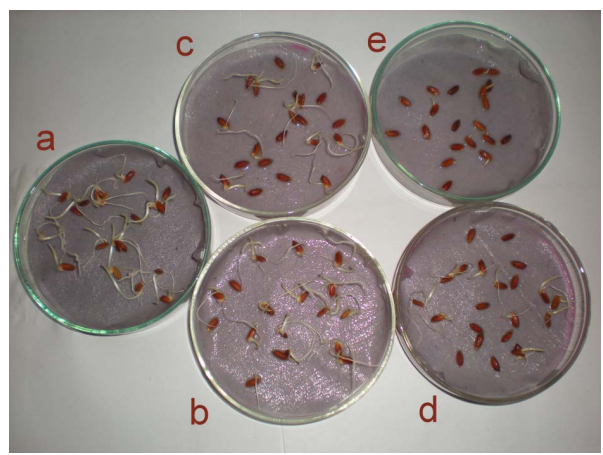

Plate 1. Effect of LAS exposure on paddy seed germination- Range finding test. (a) Control (0 mg/L LAS); (b) Test 1 (1 mg/L LAS); (c) Test 2 (10 mg/L LAS); (d) Test 3 (100 mg/L LAS); (e) Test 4 (1000 mg/L LAS).

Table 2. Reduction in peak area by the immobilized cells.

\begin{tabular}{ccccc}
\hline \multirow{2}{*}{ Peak } & \multicolumn{4}{c}{ Percentage of reduction (Expressed as peak area \%) } \\
\cline { 2 - 4 } & L9A $^{*}$ & L9P $^{*}$ & L12A $^{*}$ & 71.5 \\
3.329 & 93.385 & 30.62 & 66.4 & 77.22 \\
3.734 & 94.471 & 42.606 & 72.61 & 83.74 \\
4.912 & 95.071 & & 80.51 & 86.81 \\
4.312 & 94.893 & 74.96 & 84.42 & 88.873 \\
5.161 & 94.43 & 77.23 & 87.65 & 90.75 \\
5.641 & 94.193 & 82.12 & 89.69 & 89.675 \\
\hline
\end{tabular}

L9A: Isolate L9 in Alginate; L9P: Isolate L9 in polyvinyl alcohol; L12A: Isolate L12 in Alginate; L12P: Isolate L12 in polyvinyl alcohol.

Table 3. LAS removal by various adsorbants measured using MBAS assay.

\begin{tabular}{ccc}
\hline Sl. No. & Adsorbants & Percentage of LAS removal \\
\hline 1 & Charcoal & 11.44 \\
2 & Clay & 29.47 \\
3 & Coconut husk & 52.23 \\
4 & Rice bran & 20.65 \\
5 & Saw dust & 48.22 \\
6 & Straw & 43.73 \\
7 & Wheat bran & 30.61 \\
\hline
\end{tabular}

Table 4. Results of range finding test-paddy seedling.

\begin{tabular}{ccccc}
\hline Sl. No. & Treatment (mg/L of LAS) & Rate of germination & Seed vigour & Root length (mm) \\
\hline 1 & 0 & 100 & 1.745 & $1.528 \pm 0.4$ \\
2 & 1 & 90 & 1.323 & $1.321 \pm 0.5$ \\
3 & 10 & 30 & 0.199 & $0.64 \pm 0.4$ \\
4 & 100 & 10 & 0.047 & $0.445 \pm 0.4$ \\
5 & 1000 & 0 & 0 & 0 \\
\hline
\end{tabular}


Table 5. Results of definitive test-paddy seedling.

\begin{tabular}{ccccc}
\hline Sl. No. & Concentration of LAS $(\mathrm{mg} / \mathrm{L})$ & Total number of seedlings & Seeds that failed to germinate & Percentage of inhibition \\
\hline 1 & 0 & 15 & 1 & - \\
2 & 2 & 15 & 1 & 2 \\
3 & 4 & 15 & 5 & 7.14 \\
4 & 6 & 15 & 10 & 64.285 \\
5 & 16 & 15 & 14 & 92.857 \\
6 & 32 & 15 & 15 & 100 \\
\hline
\end{tabular}

Table 6. Estimated LC/EC values and confidence limits (EPA PROBIT ANALYSIS PROGRAM, used for calculating LC/EC values, Version 1.5).

\begin{tabular}{cccc}
\hline Point & & \multicolumn{2}{c}{ 95\% Confidence Limits } \\
\hline LC/EC 1.00 & Exposure Conc. & Lower & Upper \\
\cline { 3 - 3 } LC/EC 5.00 & 1.011 & 0.298 & 1.914 \\
LC/EC 10.00 & 10951 & 0.784 & 3.200 \\
LC/EC 15.00 & 2.769 & 1.304 & 4.241 \\
LC/EC 50.00 & 3.507 & 1.828 & 5.155 \\
LC/EC 85.00 & 9.526 & 6.775 & 13.251 \\
LC/EC 90.00 & 25.875 & 17.839 & 47.941 \\
LC/EC 95.00 & 32.776 & 21.731 & 67.083 \\
LC/EC 99.00 & 46.524 & 28.851 & 111.345 \\
\hline
\end{tabular}

alginate entrapped condition. In comparison between the organisms alginate entrapped Pseudomonas nitroreducens (L9) was found to be superior to Pseudomonas aeruginosa (L12) in immobilized condition.

The MBAS assay results were supported by the HPLC chromatogram of the immobilized cells. The HPLC analysis of the selected isolates, results given in Table 2 and Figure 2, showed a marked reduction in concentration of the LAS compared to control. In this case also Pseudomonas nitroreducens (L9) showed maximum reduction in peak area as compared to Pseudomonas aeruginosa (L12). L9 in alginate entrapped state showed an average of 94.137 percentage reduction in peak area and 64.296 in PVA matrix. L12 reduced total peak area to an extent of $84.081 \%$ in PVA entrapped application and $81.524 \%$ in alginate entrapped application compared to control. This also shows that L9 in alginate entrapped stage is very efficient and can be used for onsite LAS removal. Free cells needed a long incubation time of eight days to achieve good reduction in LAS concentration compared to immobilized cells. However all these applications were done in batch mode and investigation of biodegradation in continuous condition was necessary to perform.

In a similar study Tallur et al. [21] compared the p-cresol degradation efficiency Bacillus sp. strain PHN1 immobilised in different matrices with that of free cells. They reported that Bacillus sp. strain PHN1 immobilised in all the selected matrices in batch culture condition performed superior than free cells. According to them the increased rate of degradation of p-cresol by immobilised cells may be due to the high local cell density provided by cells entrapped in a matrix. The matrix used for cell immobilisation may also prevent direct contact between the toxic phenolic compound p-cresol and bacterial cell membrane, which in turn protected bacterial cell and increased p- cresol degradation efficiency.

Alginate as a promising immobilisation matrix was reported by many workers. Domınguez et al. [22] recommended the use of alginate immobilised Trametes hirsuta for the production of laccase enzyme and degradation 
L9 in Alginate
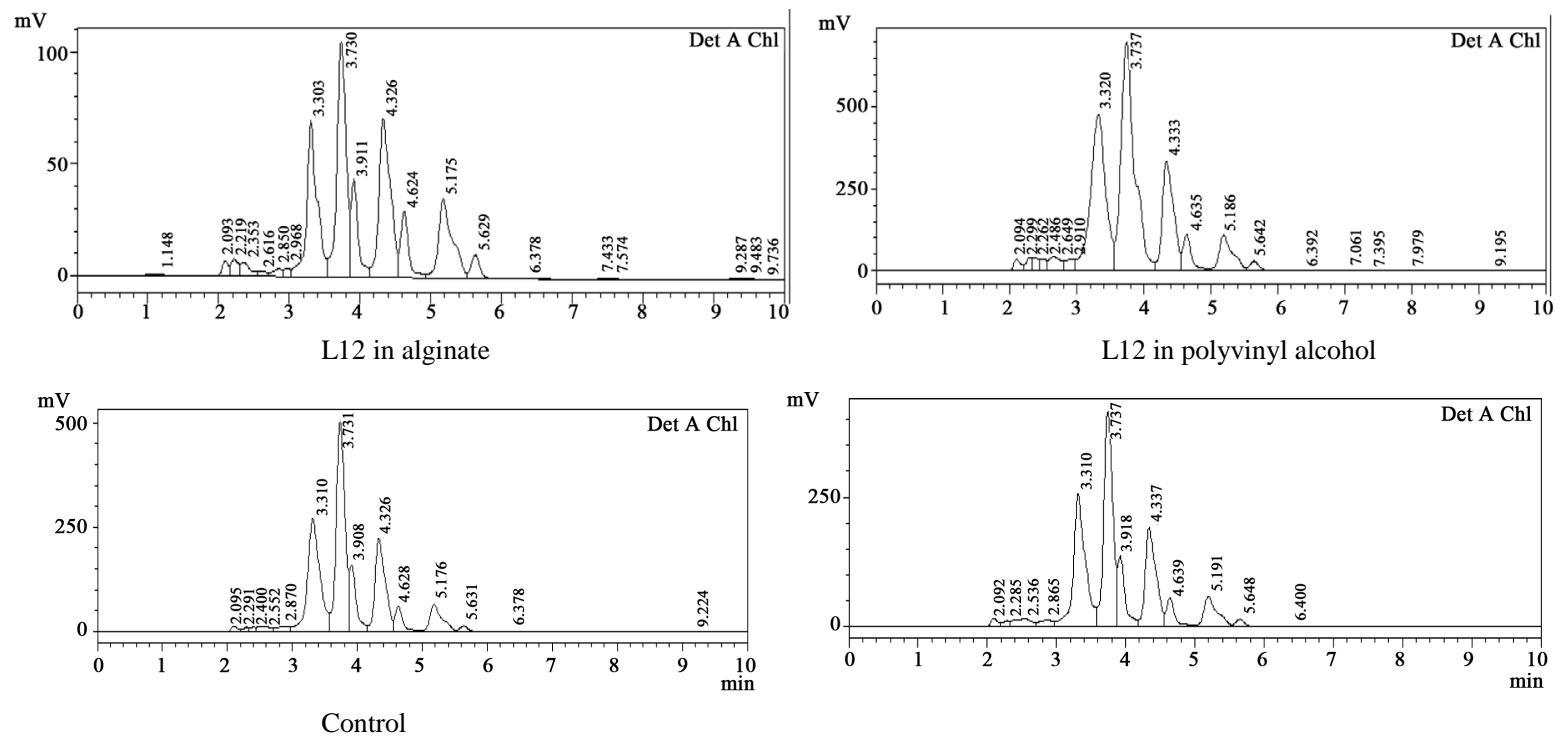

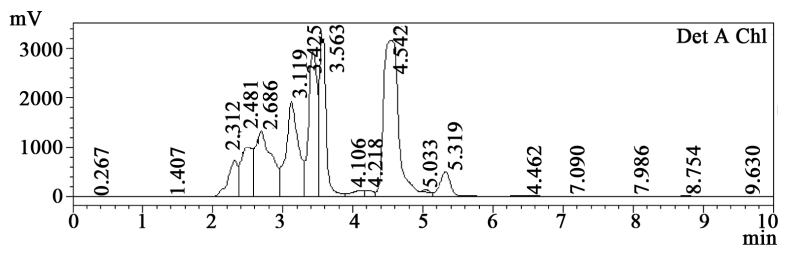

Figure 2. HPLC chromatogram of LAS degradation by the immobilized cells.

of two dyes indigo carmine (indigoid) and phenol red (sulfonaphthalein). Mohammad and Bustard [23] reported that alginate immobilised Alcaligenes faecalisis was stable and effective for converting 2-propanol (isopropanol, IPA) to acetone. According to them the beads were reused for about eight fed batch cycles and were still found to retain the efficiency of bioconversion of high concentration IPA.

Common methods of whole cell immobilization include entrapment and encapsulation. The entrapment matrix should cause as little trauma to the cells as possible; there should be reduced shock to the cells from change in temperature, osmotic pressure, chemical environment, and chemical reaction. In this study and among the various matrices available for immobilization, Ca-alginate beads stand out as the most commonly used and versatile method to date, where it fulfills the previously discussed criteria, and their production method does not require extreme reaction conditions. Ca-alginate entrapment is a simple low cost option using readily available material with low toxicity [24], and it is a promising method for enhanced microbial degradation of toxic substances [25]. This immobilization method is not directly toxic to the cells, and furthermore the dissolution of gel particles, and thus the liberation of the immobilized cells may be carried out easily and rapidly if required

In this study, a simple and effective method of immobilization was employed to augment the potential of $P$. aeruginosa to convert high concentration of LAS. Cell immobilization is thought to be the most promising approach for application of biocatalysts in various bioprocesses. Advantages of using immobilized bacteria for bioconversion reactions have been widely reported, besides making the cells easier to handle, it allows recycling of the valuable biocatalyst, and other beneficial effects such as increasing the resistance of entrapped cells towards toxic compounds, and protecting the biomass from being washed out of reactor systems [26].

The enhanced degradation by immobilized cells was probably due to the accelerated reaction rates caused by high local cell density in or on the immobilized matrix. Immobilization also provides a kind of membrane stabilization, which may be responsible for the protection of cells and better degradation rates in immobilized cell. Biodegradation potentials of this nature can be harnessed for developing biotechnologies for decontamination of polluted sites as well as water bodies.

Adsorption has been shown to be very effective in removing non-biodegradable organics from aqueous streams. Activated carbon in granular and powder form has a good capacity for the adsorption of molecules. But 
as its large scale production is not cost effective, researchers searched for the use of cheap and efficient alternative materials such as bagasse pith, carbonised bark, peat, soil, tree, and eucalyptus barks, chitin, rice husk, wood, fly ash, etc. [27]. In this study it was also found that the use of different adsorbants was effective in reducing the amount of LAS from the media. Among the selected adsorbents coir pith was found to be more effective compared to other tested materials (Table 3). Hosseini et al. [28] reported that at low pH (pH 2), rice husk could adsorbed more than $90 \%$ of anionic surfactants. However, these adsorbents are needed in bulk for large scale applications. This limits their application even though they are cheap and eco-friendly.

A range finding test was done to understand the approximate concentration of LAS test solution by selecting a broad range of concentrations. It was found that in the range $1 \mathrm{mg} / \mathrm{L}$ to $10 \mathrm{mg} / \mathrm{L}$ the germination rate reduced more than 50\% (Table 4). A definitive test was done by selecting six different concentrations of LAS. A control treatment was also maintained without LAS (Table 5). The LC50 value was calculated. The LC50 was found to be $9.526 \mathrm{mg} / \mathrm{L}$ with a lower limit of $6.775 \mathrm{mg} / \mathrm{L}$ and an upper limit of $13.25 \mathrm{mg} / \mathrm{L}$ (Table 6). The percentage of inhibition was checked. When $6 \mathrm{mg} / \mathrm{L}$ LAS was applied the inhibition rate was found to be $28 \%$ and it increased to $64 \%$ along with the increase in LAS concentration to $16 \mathrm{mg} / \mathrm{L}$.

Germination rate offers a simple method for evaluating seedling emergence and germination treatments [16]. Detergent treatment significantly affected germination rate and seed vigour of Paddy seedlings. Exposure to a LAS concentration between $1 \mathrm{mg} / \mathrm{L}$ to $10 \mathrm{mg} / \mathrm{L}$ was found to reduce the growth rate by half. At the highest selected concentration $(1000 \mathrm{mg} / \mathrm{L})$ there was no germination at all. In a similar study [29] Nand Lal and Richa Mishra reported that a marked reduction in emergence rate and vigor index was observed in detergent treated Mungbean cv. PDM 84-139 seeds.

\section{Acknowledgments}

We are grateful to the authorities of The Kerala State Council for Science Technology and Environment (KSCSTE), Sasthra Bhavan, Pattom Thiruvananthapuram, Kerala, India for the financial support provided.

\section{References}

[1] Jensen, J. (1999) Fate and Effects of Linear Alkylbenzene Sulphonates (LAS) in the Terrestrial Environment. Science of the Total Environment, 226, 93-111. http://dx.doi.org/10.1016/S0048-9697(98)00395-7

[2] Hullar, M.A.J., Kaplan, L.A. and Stahl, D.A. (2006) Recurring Seasonal Dynamics of Microbial Communities in Stream Habitats. Applied and Environmental Microbiology, 72, 713-722. http://dx.doi.org/10.1128/AEM.72.1.713-722.2006

[3] Zhang, C.L., Valsaraj, K.T., Constant, W.D. and Roy, D. (1999) Aerobic Biodegradation Kinetics of Four Anionic and Nonionic Surfactants at Sub- and Supra-Critical Micelle Concentrations (CMCs). Water Research, 33, 115-124. http://dx.doi.org/10.1016/S0043-1354(98)00170-5

[4] Mösche, M. and Meyer, U. (2002) Toxicity of Linear Alkylbenzene Sulfonate in Anaerobic Digestion: Influence of Exposure Time. Water Research, 36, 3253-3260. http://dx.doi.org/10.1016/S0043-1354(02)00034-9

[5] Dhouib, A., Hamad, N., Hassaïri, I. and Sayadi, S. (2003) Degradation of Anionic Surfactants by Citrobacter braakii. Process Biochemistry, 38, 1245-1250. http://dx.doi.org/10.1016/S0032-9592(02)00322-9

[6] D’Souza, S.F. (2002) Trends in Immobilized Enzyme and Cell Technology. Indian Journal of Biotechnology, 1, 321-338.

[7] Sasaki, H., Nonaka, J., Sasaki, T. and Nakai, Y. (2007) Ammonia Removal from Livestock Wastewater by AmmoniaAssimilating Microorganisms Immobilized in Polyvinyl Alcohol. Journal of Industrial Microbiology \& Biotechnology, 34, 105-110. http://dx.doi.org/10.1007/s10295-006-0172-6

[8] Bandhyopadhyay, K., Das, D., Bhattacharyya, P. and Maiti, B.R. (2001) Reaction Engineering Studies on Biodegradation of Phenol by Pseudomonas putida MTCC 1194 Immobilized on Calcium Alginate. Biochemical Engineering Journal, 8, 179-186. http://dx.doi.org/10.1016/S1369-703X(01)00101-2

[9] Martins, S.C.S., Martins, C.M., Fiúza, L.M.C.C. and Santaella, S.T. (2013) Immobilization of Microbial Cells: A Promising Tool for Treatment of Toxic Pollutants in Industrial Wastewater. African Journal of Biotechnology, 12, 4412-4418. http://dx.doi.org/10.5897/AJB12.2677

[10] Hayashi, K. (1975) A Rapid Determination of Sodium Dodecyl Sulfate with Methylene Blue. Analytical Biochemistry, 67, 503-506. http://dx.doi.org/10.1016/0003-2697(75)90324-3

[11] Sambrook, J., Fritsch, E.F. and Maniatis, T. (1989) Molecular Cloning: A Laboratory Manual. 2nd Edition, Cold Spring Laboratory Press, Cold Spring Harbor, New York. 
[12] Zhang, Z., Schwartz, S., Wagner, L. and Miller, W. (2000) A Greedy Algorithm for Aligning DNA Sequences. Journal of Computational Biology, 7, 203-214. http://dx.doi.org/10.1089/10665270050081478

[13] Abouseoud, M., Yataghene, A., Amrane, A. and Maachi, R. (2008) Biosurfactant Production by Free and Alginate Entrapped Cells of Pseudomonas fluorescens. Journal of Industrial Microbiology \& Biotechnology, 35, 1303-1308. http://dx.doi.org/10.1007/s10295-008-0411-0

[14] Jeong, H.-S., Lim, D.-J., Hwang, S.-H., Ha, S.-D. and Kong, J.-Y. (2004) Rhamnolipid Production by Pseudomonas aeruginosa Immobilised in Polyvinyl Alcohol Beads. Biotechnology Letters, 26, 35-39. http://dx.doi.org/10.1023/B:BILE.0000009457.42943.90

[15] Vives-Rego, J., López-Amorós, R., García, M.T., Comas, J. and Sánchez-Leal, J. (2000) Microbial Aspects of Linear Alkylbenzene Sulfonate Degradation in Coastal Water. Journal of Surfactants and Detergents, 3, 303-308. http://dx.doi.org/10.1007/s11743-000-0133-0

[16] Maguire, J.D. (1962) Speed of Germination-Aid in Selection and Evaluation for Seedling Emergence and Vigor. Crop Science, 2, 176-177. http://dx.doi.org/10.2135/cropsci1962.0011183X000200020033x

[17] Abdul-Baki, A.A. and Anderson, J.D. (1973) Vigor Determination in Soybean Seed by Multiple Criteria. Crop Science, 13, 630-633. http://dx.doi.org/10.2135/cropsci1973.0011183X001300060013x

[18] Jurado, E., Fernández-Serrano, M., Núñez-Olea, J., Luzón, G. and Lechuga, M. (2006) Simplified Spectrophotometric Method Using Methylene Blue for Determining Anionic Surfactants: Applications to the Study of Primary Biodegradation in Aerobic Screening Tests. Chemosphere, 65, 278-285. http://dx.doi.org/10.1016/j.chemosphere.2006.02.044

[19] Swisher, R.D. (1986) Surfactant Biodegradation. Vol. 18, CRC Press, Boca Raton.

[20] Thomas, O.R.T. and White, G.F. (1991) Immobilization of the Surfactant-Degrading Bacterium Pseudomonas C12B in Polyacrylamide Gel. III. Biodegradation Specificity for Raw Surfactants and Industrial Wastes. Enzyme and Microbial Technology, 13, 338-343. http://dx.doi.org/10.1016/0141-0229(91)90154-3

[21] Tallur, P.N., Megadi, V.B. and Ninnekar, H.Z. (2009) Biodegradation of P-Cresol by Immobilized Cells of Bacillus sp. Strain PHN 1. Biodegradation, 20, 79-83. http://dx.doi.org/10.1007/s10532-008-9201-7

[22] Dom Ã-nguez, A., Couto, S.R.G. and Sanroman, M.A. (2005) Dye Decolorization by Trametes hirsuta Immobilized into Alginate Beads. World Journal of Microbiology and Biotechnology, 21, 405-409. http://dx.doi.org/10.1007/s11274-004-1763-x

[23] Mohammad, B.T. and Bustard, M.T. (2008) Fed Batch Bioconversion of 2-Propanol by a Solvent Tolerant Strain of Alcaligenes faecalis Entrapped in Ca-Alginate Gel. Journal of Industrial Microbiology \& Biotechnology, 35, 677-684. http://dx.doi.org/10.1007/s10295-008-0325-x

[24] Carvalho, W., Silva, S.S., Santos, J.C. and Converti, A. (2003) Xylitol Production by Ca-Alginate Entrapped Cells: Comparison of Different Fermentation Systems. Enzyme and Microbial Technology, 32, 553-559. http://dx.doi.org/10.1016/S0141-0229(03)00007-3

[25] Westmeier, F. and Rehm, H.J. (1985) Biodegradation of 4-Chlorophenol by Entrapped Alcaligenes sp. A 7-2. Applied Microbiology and Biotechnology, 22, 301-305. http://dx.doi.org/10.1007/BF00582412

[26] Wijffels, R.H. (2001) Immobilized Cells. Springer Science \& Business Media, Berlin. http://dx.doi.org/10.1007/978-3-642-56891-6

[27] Robinson, T., McMullan, G., Marchant, R. and Nigam, P. (2001) Remediation of Dyes in Textile Effluent: A Critical Review on Current Treatment Technologies with a Proposed Alternative. Bioresource Technology, 77, 247-255. http://dx.doi.org/10.1016/S0960-8524(00)00080-8

[28] Hosseini, F., Malekzadeh, F., Amirmozafari, N. and Ghaemi, N. (2007) Biodegradation of Anionic Surfactants by Isolated Bacteria from Activated Sludge. International Journal of Environmental Science \& Technology, 4, 127-132. http://dx.doi.org/10.1007/BF03325970

[29] Lal, N. and Mishra, R. (2003) Effect of Synthetic Detergent on Germination Parameters, Seedling Growth and Photosynthetic Pigments in Mungbean (Vigna Radiata) Seedlings. Pollution Research, 22, 335-337. 